\title{
Comparison of Total Nitrogen Methods Applied for Histosols and Soil Horizons with High Organic Matter Content
}

\author{
Marcos Gervasio Pereira and Ademar Espindula, Jr. \\ Soils Department, UFRRJ-Federal Rural University of Rio de Janeiro, \\ Rio de Janeiro, Brazil \\ Gustavo Souza Valladares \\ Embrapa Monitoramento por Satélite, Parque São Quirino, \\ Campinas, Brazil \\ Lúcia Helena Cunha dos Anjos \\ Soils Department, UFRRJ-Federal Rural University of Rio de Janeiro, \\ Rio de Janeiro, Brazil \\ Vinícius de Melo Benites \\ Embrapa Solos, Rio de Janeiro, Brazil \\ Nivaldo Schultz \\ Soils Department, UFRRJ-Federal Rural University of Rio de Janeiro, \\ Rio de Janeiro, Brazil
}

\begin{abstract}
This study was carried out to correlate total nitrogen analyzed by two different methods: Kjeldahl (wet oxidation) and Perkin-Elmer 2.400 Series II-CHN Mode (dry oxidation or combustion) in Histosols and soil surface horizons with high organic matter content, sampled in different regions of Brazil. A positive correlation $(\mathrm{r}=$ $0.95^{* *}$ ) was verified between the methods, showing that Kjeldahl, because of its simplicity, can be used to routinely determine total nitrogen content in the evaluated soils.
\end{abstract}

Keywords: Histic horizons, soil chemical, tropical soils

Received 2 September 2004, Accepted 29 September 2005

Address correspondence to Marcos Gervasio Pereira, Soils Department, UFRRJ-Federal Rural University of Rio de Janeiro, BR 465 km7, 23 890-000 Rio de Janeiro, Brazil. E-mail: gervasio@ufrrj.br or lanjos@ufrrj.br 


\section{INTRODUCTION}

Nitrogen $(\mathrm{N})$ in soils is found in quite heterogeneous chemical species, although it predominates in the organic form, varying from low molar mass compounds up to complex decomposition-resistant substances (Cantarela and Trivelin 2001). The organic matter mineralization process plays an important role in the nitrogen cycle; it is responsible for the transformation of organic $\mathrm{N}$ present in plant tissues into simple inorganic forms (Franzluebbers, Hons, and Zuberer 1994). To measure $\mathrm{N}$ in soils, when it occurs as ions such as $\mathrm{NH}_{4}^{+}, \mathrm{NO}_{3}^{-}, \mathrm{NO}_{2}^{-}$, methods based on distillation or colorimetric reactions are used. The most reactive gases such as $\mathrm{NO}$ and $\mathrm{NO}^{2}$ also make determination easy, which is not the case with $\mathrm{N}_{2} \mathrm{O}$ and $\mathrm{N}_{2}$ (Tedesco et al. 1995).

Among the different methods of total $\mathrm{N}$ determination in soils, the Kjeldahl method (wet oxidation) and dry oxidation or the combustion method, also called CHN, are more frequently used. Because of its performance and simplicity, utilization of ordinary equipment, and low cost of analyses, the Kjeldahl method is the most used in routine soil and plant analysis. However, dry combustion semiautomatic devices are also available.

The objective of this study was to compare Kjeldahl (wet oxidation) and Perkin-Elmer 2.400 Series II-CHN Mode (dry oxidation or combustion) methods in the determination of total $\mathrm{N}$ in soil samples of Histosols and horizons with high organic matter content, from different regions of Brazil.

\section{MATERIALS AND METHODS}

Twenty-one samples of surface horizons, from Histosols and other soils with high organic matter content (with $\mathrm{O}$ horizon and histic $\mathrm{H}$ ), were used. They were collected in areas with different environment, soil usage, and vegetal coverage, from eight Brazilian states.

For the determination of the total nitrogen, two methods were applied: Kjeldahl (Bremner 1996) and Perkin-Elmer 2.400 Series II-CHN. In the first method, the organic $\mathrm{N}$ is converted into $\mathrm{NH}_{4}^{+}$through digestion with $\mathrm{H}_{2} \mathrm{SO}_{4}$ and metals that act as catalyzers [copper $(\mathrm{Cu})$ and selenium $\left.(\mathrm{Se})\right]$ or that further the conversion and help maintaining high temperatures during digestion $\left(\mathrm{NaSO}_{4}\right) . \mathrm{NH}_{4}^{+}$is separated after distillation by vapor carrying, resulting from the addition of concentrated $\mathrm{NaOH}$ solution to the digestion extract. The ammonia produced is carried by water vapor and collected in a boric acid solution containing the detection substance. The borate is retrotitrated with $\mathrm{H}_{2} \mathrm{SO}_{4}$ standardized solution. The amount of acid used in the titration is proportional to the $\mathrm{N}_{-} \mathrm{NH}_{4}^{+}$present in the sample.

In the dry oxidation or combustion method, the total carbon and nitrogen were determined through dry combustion, using an element analyzer, PerkinElmer 2400 CHNS (Jimenez and Ladho 1993), from $5.0 \mathrm{mg}( \pm 0.1 \mathrm{mg})$ soil samples. Acetonelida was used as reference. A detailed description of the 
Perkin-Elmer 2.400 CHNS device and function can be found in Jimenez and Ladho (1993).

The statistical method employed to compare the total nitrogen content obtained from the two methods was linear regression $\left(Y=b_{0}+b_{1} X\right)$, as suggested by Miller and Miller (1993). The null hypotheses formulated were that the declivity $\left(b_{1}\right)$ was not different from one, and the intercept $\left(b_{0}\right)$ was not different from zero. Such hypotheses were tested by means of the confidence limits calculation at $95 \%$ for both coefficients. The software adopted in the statistical analysis was the data analysis tool in Microsoft Excel 97.

\section{RESULTS AND DISCUSSION}

Total $\mathrm{N}$ values measured with both methods are presented in Table 1 and show only small variations for each soil horizon. For the Kjeldahl method, the

Table 1. Total nitrogen determined by Kjeldahl and Perkin-Elmer 2400 CHNS methods in Histosols and soils with histic horizon

\begin{tabular}{lcc}
\hline Soil samples & $\begin{array}{c}\text { N Perkin-Elmer } \\
\text { 2400 CHNS }(\mathrm{g} / \mathrm{kg})\end{array}$ & $\begin{array}{c}\text { N Kjeldahl } \\
(\mathrm{g} / \mathrm{kg})\end{array}$ \\
\hline DF1 Hap & 5.8 & 4.7 \\
DF1 Ha1 & 6.6 & 6.0 \\
DF1 Ha2 & 8.0 & 6.6 \\
ES1 Hai & 9.7 & 8.9 \\
MG1 2Hai & 17.2 & 16.8 \\
MG2 Hai1 & 7.7 & 4.9 \\
MG2 Hai2 & 11.3 & 14.1 \\
MS2 Hai & 8.0 & 7.0 \\
MS2 2Ha & 7.6 & 7.3 \\
PR2 Hap1 & 6.5 & 5.0 \\
PR2 Hap2 & 6.0 & 6.0 \\
PR2 Hap3 & 6.7 & 5.8 \\
RJ3 Hai1 & 23.3 & 22.5 \\
RJ3 Hai2 & 18.5 & 19.2 \\
RJ3 Ha & 17.8 & 21.5 \\
RJ4 Hap1 & 5.2 & 4.2 \\
RJ4Hap2 & 4.1 & 3.3 \\
RS3 Ha1 & 5.1 & 5.2 \\
RS3 Ha2 & 2.5 & 4.5 \\
SP1 Hp1 & 9.4 & 9.5 \\
SP1 Hp2 & 3.9 & 2.6 \\
\hline
\end{tabular}

Notes: DF: Distrito Federal, ES: Espírito Santo, MG: Minas Gerais, MS: Mato Grosso Sul, PR: Paraná, RJ: Rio de Janeiro, RS: Rio Grande do Sul, and SP: São Paulo. 
lowest value of $\mathrm{N}$ obtained was $2.6 \mathrm{~g} \mathrm{~kg}^{-1}$ and the highest $22.5 \mathrm{~g} \mathrm{~kg}^{-1}$. For the Perkin-Elmer 2.400 CHNS method, values ranged from $2.5 \mathrm{~g} \mathrm{~kg}^{-1}$ to $23.3 \mathrm{~g} \mathrm{~kg}^{-1}$, the highest values belonging to the RJ3 Hail soil horizon.

A comparison between Kjeldahl and Perkin-Elmer 2.400 CHNS methods for measuring $\mathrm{C}$ and $\mathrm{N}$ in weathered Brazilian soils showed only small differences between values of total $\mathrm{C}$ and $\mathrm{N}$ (Pérez et al. 2001). This similarity between methods was attributed to the soils' low content of 2:1 clays, such as the smectite, that may adsorb the ion $\mathrm{NH}_{4}^{+}$internally and to the low soil contents of $\mathrm{NO}_{3}^{-}$and $\mathrm{NO}_{2}^{-}$, which are rapidly leached in tropical environments.

A significant correlation $\left(\mathrm{R}^{2}=0.95^{* *}\right)$ was observed between the two methods of total $\mathrm{N}$ determination (Figure 1). The relationship between the nitrogen values measured by Dumas and Kjeldahl methods is described by this equation: Perkin-Elmer $2400 \mathrm{CHNS}=1.0799 \times$ (total $\mathrm{N}$ Kjeldahl) -0.9809 . The Kjeldahl method presented values statistically comparable to results obtained from the dry oxidation method. Thus, the first may be favored in routine total $\mathrm{N}$ analyses, even in the soils with high organic matter content such as Histosols.

A study with 250 soils, collected in estuarine marsh areas of North Carolina, showed a linear correlation $\left(0.986^{* *}\right)$ between total $\mathrm{N}$ content determined through dry oxidation and Kjeldahl methods (Craft, Seneca, and Broome 1991). The relationship between the two methods was described by the following equation: N Perkin-Elmer 2.400 CHNS $=1.048 \times($ total $\mathrm{N}$ Kjeldahl) -0.010 .

The equivalence between total $\mathrm{N}$ determination methods is verified through the regression analysis with the confidence interval as shown by the values of coefficient $b_{1}$ and $b_{0}$ (Table 2). The value of coefficient $b_{1}$

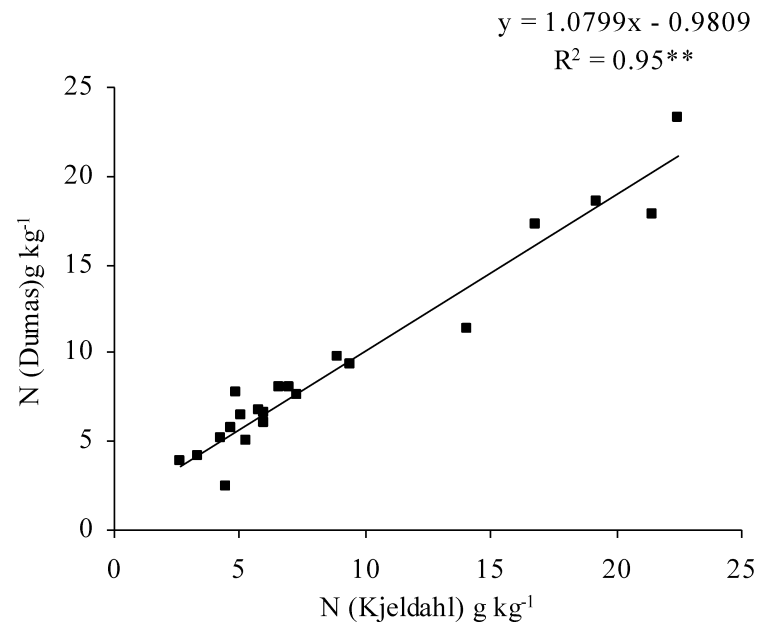

Figure 1. Correlation between soil total N measured by Perkin-Elmer 2400 CHNS and Kjeldahl methods, in Histosols and soils with histic horizon. 
Table 2. Linear regression intercept and slope $\left(\mathrm{Y}=\mathrm{b}_{0}+\mathrm{b}_{1} \mathrm{X}\right)$ for the total $\mathrm{N}$ determinations

\begin{tabular}{lccc}
\hline Coefficients & Minimum & Intermediate & Maximum \\
\hline Linear & -2.29 & Intercept $\left(\mathrm{b}_{0}\right)-0.98$ & 0.33 \\
Angular & 0.96 & Slope $\left(\mathrm{b}_{1}\right) 1.08$ & 1.20 \\
\hline
\end{tabular}

(angular coefficient) remained between 0.96 and 1.20, and the intercept average value $\left(b_{0}\right)$ showed a linear coefficient varying from a negative value $(-2.29)$ to 0.33 . These variations were not significant; therefore, the methods are equivalent.

\section{CONCLUSIONS}

The results obtained through the evaluated methods showed values statistically compatible, indicating that the Kjeldahl method, because of its performance and simplicity, may be preferred for the routine analysis of total $\mathrm{N}$, even for soils with high organic matter content.

\section{REFERENCES}

Bremner, J.M. (1996) Nitrogen total. In Methods of Soil Analysis, Part 3: Chemical Methods; Sparks, D.L. (ed.); Soil Science Society of America: Madison, Wisconsin, $1085-1121$.

Cantarella, H. and Trivelin, P.C.O. (2001) Determinação de nitrogênio total em solo. In Análise Química Para Avaliação da Fertilidade de Solos Tropicais. Instituto Agronômico de Campinas SP: Campinas, Brazil, 262-269.

Craft, C.B., Seneca, E.D., and Broome, S.W. (1991) Loss on ignition and Kjeldahl digestion for estimating organic carbon and total nitrogen in estuarine marsh soils: Calibration with dry combustion. Estuaries, 14 (2): 175-179.

Franzluebbers, A.J., Hons, F.M., and Zuberer, D.A. (1994) Seasonal change in soil microbial biomass and mineralizable $\mathrm{C}$ and $\mathrm{N}$ in wheat management systems. Soil Biology and Biochemistry, 26: 1469-1475.

Jimenez, R.R. and Ladho, J.K. (1993) Automated elemental analysis: A rapid and reliable but expensive measurement of total carbon and nitrogen in plant and soil samples. Communications in Soil Science and Plant Analysis, 24 (15-16): 1897-1924.

Miller, J.C. and Miller, J.N. (1993) Statistics for Analytical Chemistry, 3rd ed.; Ellis Horwood: Chichester, U.K.

Pérez, D.V., Alcântara, S.M., Arruda, R.J., and Meneghelli, N.A. (2001) Comparing two methods for soil carbon and nitrogen determination using selected Brazilian soils. Communications in Soil Science and Plant Analysis, 32: 295-309.

Tedesco, M.J., Gianello, C., Bissani, C.A., Bohnen, H., and Volkweiss, S.J. (1995) Análise de Solo, Plantas e Outros Materiais. Universidade Federal do Rio Grande do Sul: Porto Alegre, Brazil. 
